\title{
CODES OF BANKING ETHICS AND BANKING SOFT LAW IN POLAND
}

\author{
MAGDALENA FRAŃCZUK
}

\begin{abstract}
Codes of banking ethics are increasingly common, but practice shows that they are not of major importance to bank customers. In the article it is assumed that the codes do not fulfill their functions, including the function of protecting the consumer against fraudulent practices and abuse of the dominant position of the bank in relation to the retail client. The codes contain norms specifying the most important general clauses that are used in banking law, in particular the clause of good morals and commercial honesty. In order to comply with the principles of good practice and banking ethics, it is necessary to "stiffen" the standards of soft law which are so important that they should be clearly sanctioned. To achieve it, it is necessary to introduce to the banking soft law the information that in the case of dispute with the bank a consumer may also refer to a breach of self-regulations.
\end{abstract}

JEL Classification: K12 Contract Law, K15 Civil Law, K19 Other.

Keywords: consumer, contract, banking law, principle of commercial honesty.

\section{INTRODUCTION}

"A well-functioning consumer protection regime provides effective safeguards for retail financial services consumers while empowering consumers to exercise their legal rights and fulfill their legal obligations" [1].

Banks have an important role in society as financial intermediators and providers of payment services, especially as creditors. Banks therefore should act responsibly towards all their interest groups, including of course retail clients. This article deals with some important aspects of banking soft law. In particular, it analyzes how codes of good banking practice and codes of banking ethics work or rather could work effectively in reality. Good banking practice has evolved from practical experience. It consists of general principles governing the relationship between a customer and a bank and the banks' operating procedures.

The terms "codes of good banking practice" and "codes of banking ethics" are understood as follows: Code of Banking Ethics (Principles of Good Banking Practice) of the Polish Bank Association [PL.: Zwiazek Banków Polskich]. The author shows how the norms of soft law can gain in importance and where a common reference point in which soft law meets hard law can be found. The codes of good banking practice contain the norms on how to interpret the most important general clauses used in banking hard law, in particular the clauses of good morals and commercial honesty. These clauses combine soft and hard banking law. The author has made a few assumptions leading directly to the conclusions which may be important from the practical point of view - especially for the consumer. The 
main assumptions of the article are the following: 1) Codes of good practice and banking ethics do not function properly, in particular if the codes are considered to be an instrument protecting the consumer against fraudulent practices and abuse of the dominant position of the bank in relation to the retail client. 2) The Code of Banking Ethics (Principles of Good Banking Practice) of the Polish Bank Association includes standards to interpret the most important general clauses used in civil and business law, in particular the clauses of good morals and commercial honesty. 3) Codes of good practice and banking ethics are becoming more and more common but practice shows that they are currently not of major importance to bank customers. That's why - 4) in order to comply with the principles of good practice and banking ethics, it is necessary to "stiffen" the soft law norms that are so important that they should be explicitly sanctioned.

\section{FREedom of Business ACTIVITY AND GeNERAl ClAuSES}

The bank as an entrepreneur is bounded by Article 17 of the Act of 2 July 2004 on freedom of business activity (Journal of Laws of 2004, No. 173 item 1807 as amended), which states that an entrepreneur carries out business activity on the basis of fair competition, respects good morals and legitimate interests of consumers (these principles are clearly reflected in banking soft law). Article 17 referred to hereinabove uses undefined phrases, the meaning of which should be determined taking into account the provisions of other laws, judicial decisions and doctrine, as well as good practices adopted in commercial and business transactions. The legislator refers here to the positive aspects of doing business in the conditions of the social market economy (the principle of a social market economy is regulated in Article 20 of the Polish Constitution). In this context banks in their activity should comply with the principle of commercial honesty. Commercial honesty is a general clause which should be interpreted in the light of social phenomena and non-statutory norms and principles of moral and ethical conduct. The codes of banking ethics and the principles of good banking practice are a direct expression of these clauses and principles.

The former president of the Polish Office of Competition and Consumer Protection [pl: UOKiK] A. Jasser said that commercial honesty is the duty of every business entity and each entrepreneur towards their business partners, competitors and above all - consumers. The breach of commercial honesty strikes the strongest in consumers who are the weakest market participants. In no other sector is this phenomenon so important as in the financial sector [2].

The principle of commercial honesty is closely connected with the principle of good commercial practice. According to K. Kopaczyńska-Pieczniak, the principle of commercial honesty means the obligation to respect good practice in business. The term "good practice" is widely understood as respect for another human being. The principle of commercial honesty should be reflected in overall activity, in external and internal business relationships. The principle of commercial honesty may be regarded as a particular development of the principle of justice in the context of commercial law because of the special nature of legal relationships to which it relates. It is associated to other principles of commercial law and its violation predominantly leads to the application of civil law penalties [3, p. 161]. This aspect of the above specified principles is closely linked to Article $58 \S 2$ and Article 353 of the Civil Code. According to M. Safjan, the issue of commercial honesty plays an important role in the functioning of free market. A characteristic feature of recent years is the codification of the principles of business conduct which leads to the determination of good morals in the form of codes of ethics or codes of good practice, which is an expression of self-regulation i.e. a kind of self-limitation of entrepreneurs [4, p. 165].

\section{Code of Banking Ethics (Principles of Good Banking Practice) of the Polish BANK ASSOCIATION}

Each kind of business develops its own good customs, as is the case with banks. The principles of fair competition and commercial honesty are expressed very clearly by the Code of Banking Ethics 
(Principles of Good Banking Practice) of the Polish Bank Association. The good customs and principles of commercial honesty that underlie good banking practices and ethics can also be linked to the general clause of social coexistence. In doctrine, the general clause of social coexistence refers to the use of nonlegal rules of conduct that are universally accepted in a certain community, place and time and which are always associated with moral norms adopted in this community. According to Z. Gawlik, the concept of social coexistence should be understood as a kind of obligation - not to cross the boundaries of widely understood integrity, morality and loyalty in business relationships [5, p. 198]. In the codes of good practices, there are standards that clarify the most important general clauses used in business law, in particular the good morals clause. M. Safjan [6, p. 52] points out that the general clause of good morals is related to social norms. Law itself is in a sense delayed in relation to reality. It is important to adapt legal regulations to the changing reality - it is possible by application of general clauses which play an important role in that process. In that sense general clauses are concretized by soft law which could be regarded as a mechanism of adaptation of legal norms to new social, political and economic circumstances. A. Zurawik points out that the concept of good morals is a non-definable category, one may search the criteria of this concept in a concrete situation and find if they have been broken or not. The doctrine argues about methods to find and choose these criteria. Surely, the most important criteria are: morality, justice, honesty and decency. A. Zurawik believes that the criteria for violating good morals clause may be found among moral values that are fundamental for Christian ethics which is dominant in the Polish legal system. Legislator has adopted many basic Christian values to the legal order. They are not, therefore, values "created" by law. They are independent values on which the law is based and to which it refers. When making judgments in the light of the good morals clause, the axiological system and Christian morality that predominates our society and is expressed by the Polish Constitution (in particular in the Preamble) cannot be underestimated. Also, other features of the prevailing customs cannot be ignored [7, p. 47]. When evaluating the importance of good morals in business, the doctrine also refers to the category of custom: "Contradiction with good morals consists in breaking moral and customary norms adopted in business. There are certain rules of fair dealing, widely accepted in certain circles of entrepreneurs, whose observance ensures fair competition. This rules are arising from existing and established customs, moral, ethical or other principles formed in a certain groups of entrepreneurs including banks" (see: judgment of the Court of Appeal in entrepreneurs Warsaw from 12 July 2012, act signature VI ACa 287/12).

The values that make the content of the good morals clause are respect for the partner, fairness, sincerity, trust, loyalty, honesty and professionalism. These values are expressed in the Code of Banking Ethic of the Polish Bank Association. The Code clarifies the meaning of the clauses under discussion. Good customs and principles of commercial honesty that underlie good banking practices and ethics should also be linked to the general clause of social coexistence.

Bank self-regulatory documents provide fairly clear and precise indications as to what behavior is considered immoral or unethical and in practice is not allowed.

\section{ACts of Unfair Competition AND the General Clause of Good Morals as a LINK BETWEEN HARD AND SOFT BANKING LAW}

According to Article 3 sec. 1 of the Act of 16 April 1993 on Combating Unfair Competition (Journal of Laws 2003 No. 153 item 1503 as amended), the act of unfair competition is also a behavior contrary to good morals. In the literature, it is pointed out that the consideration of positive law without its axiological justification brings a legal regulation to a purely instrumental position. According to P. Sokal, the general clause contained in Article $3 \mathrm{sec} .1$ refers to other normative systems, -non-legal standards, in particular to good morals, which may be interpreted in different ways [8, p. 1322]. Some authors, like A. Szpunar, state that the clause of good morals has nothing to do with morality. Morality is an inner aspect of an individual's psyche, while good morals concern human behavior, have an objective, social nature [9, p. 40]. A. Baumbach [10, p. 41], in turn, states that the general clause of good morals is not about morality in a religious sense or in the sense of philosophical ethos but it should be 
considered only as the ethics of practical life. Banking soft law should find its practical dimension primarily in the clarification of general clauses, in particular the clause of commercial honesty. General clauses such as freedom of business activity (in particular Article 17 referred to in the above point 2) and to a certain extent also the principles of the European contract law are the link between widely understood banking soft and hard law. The provision which clearly indicates such a relationship between hard and soft law is Article 5 sec. 1 point 4 of the Act Combating Unfair Competition, under which unfair on market practice, which is contrary to good morals, means a failure comply with a code of good practice which an entrepreneur has voluntarily accepted.

\section{Practical Application of the Principles of Ethics and Good Banking}

\section{PRACTICES}

It needs to be stressed that banking soft law (in particular in the context of Article $65 \S 1$ of the Civil Code) may be relevant for the assessment of facts and circumstances of the conclusion and execution of a contract, in particular when the contract is subject of a dispute between a bank and a client. This possibility should be taken into consideration by both bankers and consumers or their agents in possible disputes with banks because a dispute resolution authority should always take into account all the circumstances that shape the facts and affect the outcome of the case Article $65 \S 1$ states as follows: "A declaration of intent should be interpreted in view of the circumstances in which it is made as required by principles of social coexistence and established customs". Principles of social coexistence and established customs are a general clause which enables flexibility in resolving disputes. The practical use of banking soft law (for example codes of ethics) is possible - it is allowed (inter alia) by Article 65 of the Civil Code and the regulations against unfair competition. The documents such as the Code of Banking Ethics (Principles of Good Banking Practice) of the Polish Bank Association, among others, could become an indirect, auxiliary basis of judicial decisions. They may also "strengthen" hard law regulations. The practice and knowledge about the possibility that a client of banking services can refer to a breach of a soft regulation needs to be widely disseminated in consumer awareness. It seems that the easiest way to discipline banks to comply with good banking practices and ethics would be to explicitly include in soft documents or contractual patterns clear information that in the case of a dispute with the bank a client (consumer) has the right to refer to a breach of the bank's soft rules. It would make it easier to solve possible disputes, to verify the performance of the bank's information obligations and to clarify the circumstances of the contract (in particular a credit contract). Banking soft law could be an excellent tool to protect customers. It is very important because the consumer is the weaker side of the relationship between a bank and a client. Consumers generally do not know that they may require banks to comply with banking ethics codes and good banking practices. If they were aware, they would more likely monitor the behavior of the bank in specific consumer relationships. A breach of soft law standards could result in a breach of general clauses that are contrary to the sanctioned soft law. A bank customer may only be protected by soft-law standards, if they are truly internalized and respected by the bank, otherwise they will only be an unnecessary excess of regulation for marketing purposes, in particular to build a good image and reputation of the bank.

\section{CONCLUSIONS}

It is reasonable to introduce to the codes of good practices or similar soft law documents, the information addressed to the consumers of banking services that in the case of a dispute with the bank they can refer to breach of self-regulations. Such information could also be included in the final provisions of agreements concluded by the consumer with the bank, which in particular should concern credit agreements.

A breach of ethics codes or codes of good practices is a violation of general clauses, in particular of commercial honesty and good morals. Banking soft law can be regarded as an expression of good 
traditional business practices and principles and as a return to the values devalued in modem and postmodern times - in particular to the most important value and category namely - honesty. It is assumed that codes of good banking practices in a way constitute an ethical banking system as well as the basis of good relationships between banks and clients.

Banking soft law is usually an illusory normative regulation, unless it is properly internalized. It usually has a purely utilitarian and marketing purpose and is created to guarantee the best position of the bank on the market. Notwithstanding, the soft law, in particular in the form of good banking practices and principles of banking ethics, is a link between social expectations and hard regulations. It is an answer to the crisis of confidence in banks. As a result of the crisis, the law had to give way to other normative systems and non-legal norms in order to rediscover the values that should be at its roots. In the case of the relationships between banks and customers discussed above, the first step was to refer to good commercial customs and to the category of honesty.

As mentioned in the introduction, in order to comply with the principles of good practices and banking ethics, it is necessary to "stiffen" these soft law norms that are so important that they should be explicitly sanctioned. These norms are strictly connected with general clauses discussed in this paper and should be treated as their concretization. In order to fulfill one of the most important and proper functions of the banking soft law and to treat bank selfregulations seriously, it is necessary to build consistently awareness of the customers of banking services and to show them that documents of banking soft law are a part of the widely understood banking legal system. The codes of good banking practices and the codes of banking ethics are intended also for clients, not only for banks. Their provisions should protect the interests of the customers, in particular those who are parties to credit contracts or other important contracts concluded with the bank.

\section{REFERENCES}

[1] World Bank. Good Practices for Financial Consumer Protection, Washington DC, 2012. Available at: http://documents.worldbank.org/curated/en/583191468246041829/Good-practices-for-financialconsumer-protection

[2] Uczciwość kupiecka podstawą wolnego rynku - wystąpienie Prezesa UOKiK Adama Jassera. UOKiK, (2015). Available at: https://www.uokik.gov.pl/aktualnosci.php?news_id=11410 (in Polish)

[3] Kopaczyńska-Pieczniak K. Zasada uczciwości kupieckiej jako zasada prawa handlowego. Studia Iuridica Lublinensia, 25 (1) (2016), 161-179. (in Polish)

[4] Safjan M. (red.) System Prawa Prywatnego. Prawo cywilne - część ogólna, T. 1. Wydawnictwo C. H. Beck sp. z o.o., Warszawa, 2012. (in Polish)

[5] Gawlik Z., Gajda J. Podstawy Prawa Cywilnego. Zobowiązania. Część Ogólna. Wyd. LexisNexis, Warszawa, 2003. (in Polish)

[6] Safjan M. Klauzule generalne w prawie cywilnym (przyczynek do dyskusji). Państwo i Prawo, 11 (1990), 51-53. (in Polish)

[7] Żurawik A. Klauzula generalna "dobrych obyczajów" : ujęcie teoretyczne. Ruch Prawniczy, Ekonomiczny i Socjologiczny, 71 (1) (2009), 35-51. (in Polish)

[8] Sokal P. Czyn nieuczciwej konkurencji a dobre obyczaje. Monitor Prawniczy, 24/2011. (in Polish)

[9] Szpunar A. Nadużycie prawa podmiotowego. In: Prace Komisji Prawniczej, Nr 2. Polska Akademia Umiejętności, Kraków, 1947. (in Polish)

[10] Baumbach A., Hefermehl W. Wettbewerbsrecht. C. H. Beck, München, 1996. (in German) 
Address: Magdalena Frańczuk, Cracow University of Economics, 8/7, Królewska Str., Kraków, 30-045, Poland.

E-mail: kancelaria@franczuk.com.pl

Received: 17.04.2018; revised: 06.12.2018.

Франжук Магдалена. Кодекси банківської етики та банківського “м'якого" закону у практиці республіки Польща. Журнал Прикарпатського університету імені Василя Стефаника, 6 (2) (2019), 49-54.

Кодекси банківської етики усе більше і більше стають звичними для діяльності банків, однак практика засвідчує, що вони не мають вагомо значення для банківських клієнтів. У статті припускається, що вказані Кодекси не виконують повноцінно своє призначення, в тому числі функції, пов'язані із захистом споживачів від недобросовісних дій банків та від здовживання останніми своєю домінувальною позицією щодо кдієнтів. Кодекси містять норми, які конкретизують найбільш загальні принципи, відображені у банківських нормативних актах, зокрема, принципи дотримання засад моралі та комерційної доброчесності. Належне дотримання принципів добросовісності щодо банківської етики спонукає до розгляду стандартів так званого “м'якого" закону, значення яких усе більше зростає, в зв'язку з чим виникає потреба легалізувати їх у нормативних актах. Для досягнення викладених цілей варто надати банківському "м'якому" закону можливим бути застосованим при конфліктах інтересів банку та споживача банківських послуг шляхом використання саморегудяції вирішення конфліктних ситуацій.

Ключові слова: споживач, контракт, банківське право, принцип комерційної доброчесності. 